\title{
沉用高分子工業の製造プロセスの 進歩と環境問題
}

\author{
山口興 治*
}

\section{1.はじめに}

1960 年代の日本経済の高度成長の下で，石油 化学 工業は目覚ましい発展を遂げた，石油化学工業の発展 の主役としての汎用高分子工業では，Ziegler-Natta 触媒の発明に続く種々の新しい有機金属系触媒に上る 新しいポリマーの工業化を行ないつつ，規模の大型化 による経済の効率化を主目的とした製造プロセスの変 遷が行なわれてきた。この間の代表的な沉用高分子の 生産量の増加は著しく， 統計資料"にみられるよう に, 60年代の生産量の変化は鳘異的である.

このような工業の巨大化に伴って，これらの工業に 起因する環境污染（公害）が最大の社会問題となり， 石油危機以来の資源問題(原料価格の上昇)とともに, 公害防止コストが製造プロセスの経済性に大きな影響 をもたらすよらになってきた，各企業はそれぞれの製 造プロセスから排出される環境污染物質に対する公害 防止策を研究し実施しているが，そのための設備費， 運転費は上昇の一途をたどっている，このような環境 下で，汎用高分子の製造プロセスの経済性に対するそ れらの影響について検討し，今後の製造プロセスの発 展の方向について考察した.

\section{2. 製造プロセスの経済性に影響する環境因子}

通産省の調査による民間企業の公害防止設備投資の 推移拈よびそれらの種類別内訳は通産省の調查 ${ }^{2)}$ に示 されるように，全業種で見ると大気污染防止施談が半 分以上を占め，次に水質活濁防止施設が続いている が，化学工業あるいは石油化学工業ではそれらが添 同程度のウ土イトを占めている，これらから，ポリマ

* Koji YAMAGUCHI 宇部興産株式会社 石油化学事 業部(100 東京都千代田区霞ヶ関 3-7-2) 技術部長 Progress in Manufacturing Process of General Purpose Polymers and Environmental Pollution
一の製造プロセスに影響を与古る因子としては，主に 大気污染に関連する電力，スチーム，主に水質污濁に 関連する溶剤および水が主要なものであると考㝋てよ いであらう。

\section{2-1. 電 力}

火力発電に括ける脱硫経費 ${ }^{3}$ は 0.5 円/kWH 程度 であるが，脱硝経費 ${ }^{3}$ は 1 2 円/kWH となり，環境 基準の設定により，電力量に対する大気污染防止経費 が大きなウェイトを占めてきており，数年前は 4〜 5 円/kWH であったものが既に 9 円/kWH 程度にま で上昇してきて栉，これには国の省資源のための政 策的な意味む含まれているようである，従って電気エ ネルギーを大量に消費するような製造プロセスは経済 的に不利になっていくと考学られる.

\section{2-2. スチーム}

スチームの場合も電力と同様に大気污染防止コス卜 が上昇していくが，重油 $1 \mathrm{~K} l$ あたりのスチーム約 15 . $\mathrm{t}$ とすると，脱硫経費は約 150円/ $\mathrm{t}$ 程度で，脱硝経費 は約 $250 \sim 500$ 円 $/ \mathrm{t}$ となる. 数年前に約 800 円/ $\mathrm{t}$ であ. ったすのが，既に 2500 円/ $\mathrm{t}$ 程度まで上昇している. 従って，このようなスチームを大量に使用する製造プ 口セスは，石油の価格上昇と環境基準の厳格化に伴い 経済的に不利になっていくことが予測される.

\section{2-3. 溶㓮および水}

工場廃水は中和法, 凝集沈殿法, 沪過法などの物理. 化学的処理法や，活性污泥法のような生物処理法によ って処理されていることが多いが，これらの処理法で は限度があるため，活性炭吸着法のような三次処理技。 術について研究が進められて扣り，高度の浄化水を得 ることがでさるようになってきているが，処理方式が. 複雑になるにつれて処理コストは大幅に上昇してく る4). 従って，水や溶剤の使用量も環境問題に関遗し て製造プロセスの経済性に影響を及ぼす大きな因子で あり，プロセスを比較する場合に注目すべき項目の一。 つである。 


\section{3. 汎用高分子工業の製造プロセスの比較}

プラスチックの分野で生産量の多いポリエチレン, ポリプロピレン，ポリ塩化ビニル，ポリスチレン和よ び ABS 樹脂を沉用高分子の代表として選び, これら の製造プロセスについて検討した. これらのポリマー の製造プロセスは，次に示すような重合様式によって 大きく分類することができる.

塊状重合プロセス

懸濁重合プロセス

乳化重合プロセス

溶液重合プロセス

これらのプロセスの選択に当っては，使用される重 合触媒の性質が大きな因子の一つであるが，工業化の 時点においてこれらの重合工程だけでなく, それに伴 らポリマーの分離, 精製, 溶媒や未反応物の回収, 公 害防止など製造プロセス全体の経済性の評価に基づい て決定されるのであり，最近は省資源，省エネルギ 一, 脱公害の観点が重要性を増してきている，もらろ ん，このようにして選ばれる製造プロセスの操業性, 安全性あるいは得られるポリマーの性質に対する市場 の要求は非常に重要な点であるが，ここでは製造プロ セスの経済性に焦点をしばって考えてみたい:

\section{3-1. ポリマー製造プロセスの特徴}

前記の四つの重合様式は，それぞれ他のプロセスに ない特徵を持って和り，様々な構造や特性をもったポ リマーの製造に用いられている.これらの分類の中で も反応装置の形式や運転の方法恪企業の独自のもの となって拉り，同じポリマーでもいるいろの特幑を持 った品種が作られている. 従って，一般的な取り扱い には問題があるが，上記の大分類に従って各プロセス の特徵を次に述べてみる.

\section{3-1-1. 塊状重合プロセス}

塊状重合プロセスは古くから高压ポリエチレンやポ リスチレンに用いられて工業化されており，重合系が モノマーのみで，重合法としては基本的な最も単純な プロセスであり，どのような触媒とモノマーを用いる 重合反応にも適用できるといら汎用性があるが，高圧 ポリエチレンやポリスチレン以外のポリマーの重合プ ロセスとしてはあまり採用されなかった，その理由 は，重合系全体が活性なモノマーであるために反応の 制御が難しかったこと，あるいは重合工程の後で水や 溶剤を用いる複雑な分離精製工程が必要な場合にはあ まりメリットがないことなどである.

ところが最近になって BASF 社や UCC 社のポリ エチレソやポリプロピレンの気相塊状重合プロセスが 工業化された，これは気相重合プロセスによって反応
の制御の問題が解決され，また触媒の改良によって触 某残渣やアタクティックポリマーあるいはワックスの 除去が不必要になったためである.

このように，塊状重合プロセスは他の重合プロセス に比べて単純であり，反応の制御，分離工程などの関 連の工程との関係，ポリマーの性質などの問題が解決 できれば，あらゆるポリマーに適用されていくことが 予想される.

\section{3-1-2. 懸濁重合プロセス}

懸濁重合プロセスは水中にモノマー粒子を分散させ て重合する方法で，ポリ塩化ビニルやポリスチレンが この方法で工業化されている. 重合反応は塊状重合と 同じで単純な製造プロセスであるが，重合系に水が存 在するので, 塊状重合に叔いて発生する反応熱の除去 や暴走反応の解決に有利なプロセスである. 䀣濁重合 プロセスでは反応中のモノマーを水中に安定して分散 させることが重要であり，また重合が進んで粘稠にな った分散滴が反応器の壁面に付着してスケールと呼ば れるものが生成することが，操業上およびポリマーの 品質上の問題である，このプロセスは回分式であり， 連続操作に発展する可能性はまだないようであるが， スケールの付着防止，洗浄法の改善などによって反応 器の大型化が可能となり, 完成度の高いプロセスとな っている. このプロセスの最大の久点は，媒体に水を 用いるため, 水に対して不安定な触媒は使用できず, Ziegler-Natta 触媒発見以後に出てきた有機金属触媒 系を用いる多くの新しいポリマーにこのプロセスを利 用できないといら沉用性に欠ケる点である。

\section{3-1-3. 乳化重合プロセス}

乳化重合法は石けんミセルが存在する水溶液に, 水 に難溶性のモノマーを加えてミセル中に分散させ，水 溶性のラジカル触媒によって重合するもので, SBR のような合成ゴムおよび ABS 樹脂がこの方法で工業 化されている.このプロセスの利点は懸濁重合プロセ スと同様に塊状重合法の問題である反応熱の除去が容 易であることにあり，また㢡濁重合法の場合よりもポ リマー粒子が小さく，分散粒子の安定性が良く連続重 合が可能なことである.このプロセスのもら一つの利 点はその重合機構の特徵から，プラスチックにゴムを ミクロに分散させて耐衝慗性を持たせた ABS 樹脂が 製造されているように，異種ポリマーをグラフト重合 させることによって，特異な性質をもったポリマーを つくることができることである.しかし，このプロせ スも䜿濁重合法と同様に水を用いるために沉用性に欠 け，また乳化剤を大量に使用するために製品への不純 物の混入が多く，品質を悪くする可能性がある. 従っ て，他の汎用ポリマーの製造プロセスとしての展開の 
可能性はないように思われる。

\section{3-1-4. 溶液重合プロセス}

溶液重合プロセスには生成したポリマーが溶媒に溶 好て均一相となる溶液重合と，生成したポリマーが析 出して溶媒中にスラリーとなって分散するいわゆる溶 媒スラリ一重合とがある，溶媒スラリ一重合の場合に 性, 溶液重合の場合の溶液粘度の問題性解決される が，スラリーの沈股，付着などの問題があり，いずれ の場合飞も反応の制御，ポリマーの分離，精製などの 各工程とも複雑で, 設備費も製造コストも大きいプロ セスである、しかしこの重合法は，Ziegler-Natta 触 媒の発明以来続々と現われてきた新しい有機金属触媒 系を用いることができるため，新しいポリマーは注と んぞこのプロセスによって作られているょうに，すぐ れた沉用性をるつプロセスである. 従って, このプロ セスの問題点である複雑な後处理工程の問題を解決す るため，多くの企業の研究陣が努力してきている．炎 の一つの現われが高密度ポリエチレンの製造プロセス そ特ける無脱灰プロセスの開発である. その一つの方 法は，反応条件を変兄て触媒效率を飛躍的信めるこ とによって触媒除去工程を不要にした反応条件変更型 であり, DSM 社のコンパクト・プロセスや Phillips 社の HSS プロセスがある。またもう一つの方法は活 性の非常に高い触媒を開発して，これを適用すること によって無脱灰プロセスを可能にした高活性触媒開発 型のアプローチであり, Solvay, Phillips の PF プ ロセス, Montedison, Hoechst, 三菱化成などの方法 が開発され工業化されてきている.

\section{3-2. 汎用ポリマーの製造プロセスとコストの比較}

各ポリマーの製造プロセスはその工業化の時点に拈 いて安全性, 操業性, ポリマーに要求される特性, 環 境問題などを含めた経済性を検討され，選択されてき ている、これらの製造プロセスのコストを比較しそ の優劣を評価することは，異種ポリマーの間ではもと より，同種のポリマーの場合にす製造される品種が多 岐にわたるため非常に困難である，佐伯氏5)はモノマ 一比・重合用薬剤・ニーティリティ・その他に分けて ポリマーの原価構造を示し，

[ポリマー製造原価 $]$ 一モノマー費 $]=[$ 製造技術費 $]$ として，【製造技術費〕の小さいもの活ど，その製造 プロセスの経済性は高く；合理化され，完成度が高い という見方をしている。これ性非常に與味のある解析 法であり，われわれもこれを試みて同様な傾向の結果 を得て拈り，石油危機以来の諸物価の变動のため絶対 值による取り扱いは難しくなっているが，このような データによって各プロセスの問題点を明らかにするこ とができる，さらにこれに資源拉よび公害の問題を考
慮して原価構成の変化の可能性について检討するため には，モノマー費以外の構成要素についても注目する 必要がある. 次にこれらについて可能と考兄られる籁 囲内で比較を試みる。

第 1 表拈よび第 2 表 ${ }^{6}$ 亿沉用ポリマーの原価構造を 示した.これらは原料価格の急上昇以前のデータに基 づいているために現状とは異なる点もあるが，その構 造はそれぞれの製造プロセスの特徵を表わしている. 第 1 表に示したものはモノマー費の構成比が小さく完 成度の低いプロセスであり，高密度ポリエチレンやポ リプロピレンに和いて見られるように，プロセスの改 良・開発によってモノマー費の構成比を上げる余地が 残されている. 第 2 表に示されたるのはモノマー費の 構成比が比較的大きく，今後の技術開発によってコス トダウンできる余地が少ない，第 1 表㧊よび第 2 表を 利用して，現在のモノマー価格を基礎にして総原価を 算出し，これを計算基準として2。で述べた製造プロ セスの経済性に影響する環境因子としての電力・水· スチームのコストが 2 倍になった場合の原価の增加額 を第 3 表特よび第 4 表に示した．これらの值は総原価 の中でこれらの因子に対応する原価であると考觉てる よい，計算基準原価として示した総原価は現状と必ず しも合致しないが，電力費などの変化の影響を見るた めには十分利用できると考克，各ポリマーについてそ の製造プロセスを倹討する。

\section{3-2-1. ポリエチレン, ポリプロピレン}

これらのポリマーの場合は，第1表に示されるよう 飞原価構造の中で原料モノマーの占める割合が小さ いが，その他の要素の割合はそれぞれの採用している 製造プロセスの特徵を表わしている.

(1) 高圧ポリエチレンは管型または槽型の反応器で それぞれ特徵のあるポリマーが製造されているが，原 洒構造は注とんど変わらないので, 第 1 表では一つの 代表值で示した．いろいろな製造プロセスの中で最も 単純な塊状重合プロセスであるが，反応熱除去の問題 のため反応率は 10〜20\% に抑兄られ，高圧を使用す るために反応器, 圧縮機气の他の設借機器には十分な 安全性が必要でそのための設備投資額が大きく，償却 費の原価に占める割合が大きくなって扬りまた高圧 ・大容量の圧縮機による電力消費量が大きい。他のプ 口セスと比較しても，第 3 表に示されるよう電力費 の上昇の影響を最も大きく受けるプロセスである.こ のプロセスで，反応速度は現状のように瞬間的に行な われる状態で，反応圧力を下げて，one-pass での反 応率を上げて，必要な特性を持ったポリマーを製造で きるプロセスが開発できれば，大幅なコストダウンが 可能である. 
第 1 表 ポリエチレン，ポプロピレンの原価構造（構成比 \%)

\begin{tabular}{|c|c|c|c|c|c|c|c|c|c|c|c|c|c|c|c|}
\hline \multirow{2}{*}{ 樹 脂 } & \multirow{2}{*}{ 重合法 } & \multirow{2}{*}{ Eノマ } & \multicolumn{4}{|c|}{ 副 原 料 } & \multicolumn{5}{|c|}{ ユーティリティー } & \multirow{2}{*}{ 償却費 } & \multirow{2}{*}{ 労務費 } & \multirow{2}{*}{ その他 } & \multirow{2}{*}{ 備 } \\
\hline & & & 触媒 & 溶媒 & $\left|\begin{array}{l}\text { その } \\
\text { 他 }\end{array}\right|$ & 合計 & 電力 & 水 & $\left|\begin{array}{l}\text { ス } \\
-ム\end{array}\right|$ & $\left|\begin{array}{l}\text { その } \\
\text { 他 }\end{array}\right|$ & 合計 & & & & \\
\hline LDPE & 塊状重合 & 31.8 & 0.3 & 0.2 & $5.7 \mid$ & 6.2 & 9.1 & 0.2 & - & $一$ & 9.3 & 12.5 & 5.2 & 35.1 & |オートクレーブ \\
\hline HDPE & 溶媒スラ & 24.7 & 1.9 & 1.0 & 10.6 & 13.5 & 2.3 & 0.8 & 4.6 & 0.1 & 7.8 & 15.4 & 11.8 & 26.7 & 従 来 法 \\
\hline HDPE & リ一重合 & 33.7 & 0.5 & 1.5 & 7.4 & 9.4 & 2.5 & 0.3 & 0.5 & 0.2 & 3.5 & 13.7 & 9.8 & 29.9 & $\begin{array}{l}\text { フィリップス } \\
\mathrm{PF} \text { プロセス }\end{array}$ \\
\hline HDPE & 気相重合 & 37.2 & 1.8 & 0.7 & 9.3 & 11.8 & 6.3 & 0.3 & & 0.8 & 7.4 & 10.0 & 4.8 & 28.8 & UCC 法 \\
\hline $\mathrm{PP}$ & $\begin{array}{l}\text { 溶媒スラ } \\
\text { リー重合 }\end{array}$ & 28.1 & 3.6 & 3.7 & 8.5 & 15.8 & 3.6 & 0.3 & 3.6 & - & 7.5 & 11.7 & 6.3 & 30.6 & 従 来 法 \\
\hline $\mathrm{PP}$ & 気相重合 & 32.5 & 0.4 & 0.1 & 8.3 & 8.8 & 5.1 & 0.4 & 0.1 & 0.6 & 6.2 & 9.8 & 6.3 & 36.5 & BASF 法 \\
\hline
\end{tabular}

第 2 表 ポリ塩化ビニル，ポリスチレン，ABS 樹脂の原価構造（構成比％）

\begin{tabular}{|c|c|c|c|c|c|c|c|c|c|c|c|c|c|c|c|}
\hline \multirow{2}{*}{ 栰 脂 } & \multirow{2}{*}{ 重合法 } & \multirow[b]{2}{*}{ モノマ- } & \multicolumn{4}{|c|}{ 副 原 料 } & \multicolumn{5}{|c|}{ ユーティリティー } & \multirow{2}{*}{ 償却費 } & \multirow{2}{*}{ 労務費 } & \multirow{2}{*}{ その他 } & \multirow{2}{*}{ 備 } \\
\hline & & & 触煤 & 溶戍 & $\left|\begin{array}{l}\text { その } \\
\text { 他 }\end{array}\right|$ & 合計 & 電力 & 水 & $\left|\begin{array}{ll}ス & チ \\
\text { ーム }\end{array}\right|$ & $\begin{array}{l}\text { その } \\
\text { 他 }\end{array}$ & 合計 & & & & \\
\hline PVC & 悬 濁 & 49.7 & 0.9 & - & 3.9 & 4.8 & 1.4 & 0.3 & 0.7 & 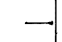 & 2.4 & 10.5 & 10.0 & 22.7 & \\
\hline \multirow{3}{*}{ PSt } & 〔塊一塊 & 48.8 & 0.4 & & 5.9 & 6.3 & 2.3 & & & & 2.3 & 8.6 & 10.4 & 23.5 & $\begin{array}{l}\text { バルク -プレス } \\
\text { プロセス }\end{array}$ \\
\hline & 塊一慗 & 63.4 & 3.0 & & 6.2 & 9.2 & 2.5 & 0.1 & 1.0 & - & 3.6 & 5.3 & 4.9 & 13.7 & \\
\hline & 乳一乳 & 41.3 & 0.8 & & 11.0 & 11.8 & 1.6 & 0.2 & 0.3 & - & 2.1 & 10.0 & 7.2 & 27.5 & $A S+B$ \\
\hline \multirow[t]{2}{*}{$\mathrm{ABS}$} & $\{$ 塊一㹂 & 50.9 & - & - & 6.1 & 6.1 & 1.6 & 0.1 & 0.4 & - & 2.1 & 8.6 & 4.4 & 27.9 & $A S+P B$ \\
\hline & 溶 液 & 46.2 & 3.4 & 0.2 & 2.9 & 6.5 & 1.1 & 0.3 & 3.6 & 0.1 & 5.1 & 11.9 & 6.1 & 24.4 & $\mathrm{EPDM}+\mathrm{S}+\mathrm{A}$ \\
\hline
\end{tabular}

第 3 表 ニーティリティーコスト上昇による各プロセスのコストへの影響 $(1)$ *

\begin{tabular}{|c|c|c|c|c|c|c|}
\hline \multirow{2}{*}{ 樹脂 } & \multirow{2}{*}{ 重 合 法 } & \multirow{2}{*}{$\begin{array}{l}\text { 計 算 基 準 } \\
\text { 原価 }\left(円 / \mathrm{kg}^{2}\right)\end{array}$} & \multicolumn{4}{|c|}{ ユーティリティーコストによる原価増（円 $/ \mathrm{kg}$ ) } \\
\hline & & & 電 力 & 水 & スチーム & 合計 $(\%)$ \\
\hline LDPE & 塊 状 重 合 & 252 & 22.9 & 0.5 & 一 & $23.4(9.3)$ \\
\hline \multirow{3}{*}{ HDPE } & 涳坢 & 324 & 7.5 & 2.6 & 14.9 & $25.0(7.7)$ \\
\hline & 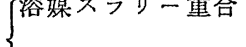 & 237 & 5.9 & 0.7 & 1.2 & $7.8(3.3)$ \\
\hline & 気 相 重 合 & 215 & 13.6 & 0.6 & $\ldots$ & $14.2(6.6)$ \\
\hline \multirow{2}{*}{ PP } & (溶媒スラリー重合 & 231 & 8.3 & 0.7 & 8.3 & $17.3(7.5)$ \\
\hline & $\left\{\begin{array}{l}\text { 気 相 重 合 } \\
\end{array}\right.$ & 200 & 10.2 & 0.8 & 0.2 & $11.2(5.6)$ \\
\hline
\end{tabular}

* 表中の各欄は第 1 表の対応する欄の製造プロセスに対する值である.

第 4 表 ユーティリティーコスト上昇による各プロセスのコストへの影響 $(2) *$

\begin{tabular}{|c|c|c|c|c|c|c|c|c|}
\hline \multirow{2}{*}{ 樹脂 } & & \multirow{2}{*}{ 重 合 } & \multirow{2}{*}{ 去 } & \multirow{2}{*}{$\begin{array}{l}\text { 計 算 基 準 } \\
\text { 原価 }(\mathrm{M} / \mathrm{kg})\end{array}$} & \multicolumn{4}{|c|}{ ユーティリティーコストによる原価增（円/ $\mathrm{kg}$ ) } \\
\hline & & & & & 電 力 & 水 & スチーム & 合計 $(\%)$ \\
\hline PVC & 懸 & 濁 重 & 合 & 177 & 2.5 & 0.5 & 1.2 & $4.2(2.4)$ \\
\hline \multirow{2}{*}{ PSt } & $\{$ 塊 & 状一塊 & 状 & 273 & 6.3 & - & 一 & $6.3(2.3)$ \\
\hline & 塊 & 状 一 䈍 & 濁 & 201 & 5.0 & 0.2 & 2.0 & $7.2(3.6)$ \\
\hline \multirow{3}{*}{$\mathrm{ABS}$} & (乳 & 化 一 乳 & 化 & 296 & 4.7 & 0.6 & 0.9 & $6.2(2.1)$ \\
\hline & $\{$ 塊 & 状 一 酥 & 濁 & 287 & 4.6 & 0.3 & 1.1 & $6.0(2.1)$ \\
\hline & & 液＼cjkstart重 & 合 & 400 & 4.4 & 1.2 & 14.4 & $20.0(5.0)$ \\
\hline
\end{tabular}

* 表中の各欄は第 2 表の対応する欄の製造プロセスに対する值である. 
（2）高密度ポリエチレンは Phillips 法やStandard 法による中王溶液重合法や Ziegler 法による 低圧溶 媒スラリ一重合法などで製造されて扔り，溶液重合の 特徴として分離, 回収, 後処理などの工程が重要なプ ロセスである. 最近になって重合条件や触桇の改良に よって，製造プロセスは大きく変化していきつつあ る. 高活性触媒による無脱灰プロセスは前に述べたよ うに数社で開発されて和り，またUCC 社では気相重 合法を開発して工業化している。これらの製造プロセ スによる高密度ポリエチレンの原価構造は第 1 表に示 されているように，技術開発に伴って原料モノマーの 構成比が大きくなり，償却費の比率も低下してきてお り, 従来の高圧ポリエチレンよりるコスト的に有利に なってきている.これは脱灰プロセスを省いて工程を 簡素化したことが大きく貢献していることを示してい る. 溶媒スラリー重合で高活性触媒を使用する場合と 気相重合の場合では，現在のコストでは気相重合の方 が有利であるが，第 3 表に示されるように，電力費が 上昇した場合には気相重合の方がその影響を大きく受 けることは注目すべきである。このことは，UCC 社 の気相重合プロセスに特いても，まだいろいろの解決 すべき問題があることを示している.

（3）ポリプロピレンの場合る, 高密度ポリエチレン と同様であるが，さらに，アタクティックポリマーの 分離工程があるため, 後処理工程の簡素化は非常以重 要である，従来から，触媒の活性を上げること拉よび タクティシティーを上げることを目的として触媒の改 良が行なわれ，数多くの特許が出されているが，最近 は Solvay 社の触媒のように高活性・高タクティシテ ィーのものも開発されてきて㧍う，また BASF 社の 気相塊状重合プロセスの開発などによって, 工程の簡 素化の可能性が出てきている. 第 1 表沶されるよう に, 気相重合プロセスでは原料モノマ一費の構成比が 大きくなり，総原価が低下していることが示され，後 処理工程の簡素化が有効に働いていることがわかる が，第 3 表に示されるように，電力費の上昇の影響は 大きく受けるので，この点については今後の展開に打 いて注意しなければならない，BASF法に物いて，触 媒や溶剮の使用量が少なくなっていることは，公害対 策上非常に有利であると考学られる.

\section{3-2-2. ポリ塩化ビニル, ポリスチレン, $\mathrm{ABS}$ 樹脂}

これらのポリマーの原価構造は第 2 表に示されるよ らに，原料モノマー費の構成比が大きく，製造プロセ スとしての完成度は高いとみることができる，また第 4 表より，ニーティリティーのコスト上昇の影響む， 特殊なるのを除けば小さいことを示している.

（1）ポリ塩化ビニルはあらゆる重合様式で重合され
るが，現在工業的には主に懸濁重合法で製造されてい る. ポリ塩化ビニルの歴史は古く，そのプロセスは曔 濁重合プロセスの典型であり，その特徴は 3-1-2. で 述べたと呿りである.

（2）ポリスチレンもポリ塩化ビニルと同様に歴史が 古く, 各種の重合プロセスが開発されているが，現在 工業的には主として塊状重合あるいは懸濁重合プロセ スが用いられている. 奬渴重合プロセスは医とんどが 回分式で行なわれているが，塊状重合の場合は連続重 合法や多段重合法などる工業化されている，第 2 表に 揭げたものはいずれも回分式で，塊状でプレポリマー を作ったのち，プレスリアクターで重合率を上げるバ ルクープレス重合プロセスと, プレポリマーを作って から懸湌重合によって重合率を上げる塊状一悠溜重合 プロセスである.これらはいずれるハイインパクト・ ポリスチレンであるが, データの都合で生産量の異な るものを用いたため, 生産量の少ない塊状一塊状プロ セスの方が不利になっているが，それでるな和原料モ ノマー費の構成比の高い原価構造となっている。 また 第4 表で見ると, ニーティリティーコストの変動の影 響は少ないが，やはり繋濁重合プロセスの方が影響は 受けやすいようである.

（3）ABS 樹脂の場合はゴムとプラスチックの組み 合わせやその構成比を変えること元っって，特異な性 質を持つ品種が作られるため，それらの重合渚合の 良い重合プロセスが選ばれるので，そのま各プロセ スを比較することはできないが，乳化重合に接ける大 量の乳化剂の使用は水質污濁の面で注目すべきであ り，溶液重合に乾けるスチームのコスト上昇の影響が 大きいことは注意すべきである.

いずれにしても，プロセスの特徵として述べたよう に，これらの製造プロセスによる将来への展開は期待 できないよら思われる。

\section{4. ポリマー製造プロセスの今後の方向}

環境問題の影響について比較検討するには，各企業 に抢忷る排出物・廃棄物特よびそれらの处理法につい ての具体的なデータが必要であるが，それらは各企業 に個有のものであり，一般的には論じられない，その ためこれらを概括的見るために，ニーティリティー の要素として電力・スチーム・水を取り上げ，また副 原料の中の触某和よび溶剂の使用量をコストの構成要 素として拔き出してみた：エネルギーコスト・廃水処 理コストなどは2.で述べたように，公害問題の発生 に伴う環境基準の強化㧍よび資源問題からくる原料価 格の上昇によって急激な上昇を示している.これらに よって各ポリマーの製造プロセスの相対的な経済性に 
どのような変化があるかを考党，将来の方向について の検討を試みてきた，第 1 表のデータが将来の方向を 示唆しているよう飞思われる，すなわち，高活性触媒 の出現と，気相塊状重合法の開発である，これらはま だいろいろな未解決の問題をかかえていると思われる が，工程の簡素化を実現し，塊状重合からの展關の可 能性を示している.

ポリマー製造プロセスそ拈いて，あらゆる問題を含 めた経済性を考克るとき，工程の簡素化は最も望焉し い力向である. 塊状重合法は他の重合法に比べて最も 沉用性があり，重合系はモノマーだけであるので，こ れから出発して最小限の触媒によって短時間に重合を 行ない，最小限の処理工程を経て要求される特性を持 つポリマーを得ることが理想的である。これを実現す ることは非常に多くの努力と年月を要すると思わ机る
が，既に着実にその方向にむかって前進しており，い ろいるなポリマーに㧤いてその方向一一歩前進したプ 口セスが帮現されていくものと考兄られ，われわれも その方向にな譄の努力をしていきたいと教克てい る.

\section{文 献}

1) Plastics Age Encyclopedia, 1972, 708

2）通産省の調查：産業之環境，6，37 (1975)

3）例えば，週間ダイヤモンド，1975年7月 5 日， 「湿式法によるNO 除去 “MON” プロセス」(三 菱化工機, 石化協会議室にて)など

4）例兄ば，北川晆夫：環境技術，2,[4]，267（1973）

5）佐伯康治：ポリマー製造プロセス(工業調査会刊) p. 334

6) Hydrocarbon Processing, Nov., 1973, 164 な ぞ，および主として個人的情報による

\section{（657 頁よりつづく）}

5）日特開昭 46-5640（ICI，BP 1970)

6) US 3324095 (UCC, 1967) US 3324101 (UCC, 1967)

7）日特公 昭49-34758 (三菱化成) 日特公 昭49-34759 (三蓉化成)

8) F.J. Karol, G. L. Karapinka, C.Wu, A.W. Dow, R. N. Johnson, W. L. Carrick ; J. Polym, Sci., $A-1,10,2621$ (1972)

9）日特公 昭49-22955 (チッソ)

10）日特公 昭49-17872（日石樹脂化学）

11）日特公 昭49-24995（三菱油化）

12) ACS Plymer Preprints, (No. 1), 27(April, 1975)

13) ドイッ特許 DT 2256-695 (VEBA)

14）日特公昭 49-17873, 昭 49-35072, 昭 49-33597 (三井東圧)

15）日特公 昭 49-17034, 昭 49-32670 (炤和電工)

16) $\mathrm{BE}-807714$ (BASF)

17) 日特開 昭 48-75686（三菱油化）

17b) 日特公 昭49-23319（東洋ストウフォー）

18）日特公昭49-28674（東洋ストウフォー）

19）オランダ特詐 NL 7309727, 7309729 (ICI)

20) ドイッ特許 DT 2301898 (三菱化成)

21) オランダ特許 NL 7211776 (Stamicarbon) オランダ特許 NL 7217658 (Italiana Resine) US 3642746 (三井石油化学)

22) ベルギー特許 BE 805264 (Montedison) ベルギー特許 BE 799977 (Solvay) US 3859231 (Gulf Res)
ドイッ特許 DT 2406784（日石）

23）日特公 昭46-34095 (三井石油化学)

ドイッ特許 DT 2255717 (チッソ)

24.) 日特公 昭47-26383 (三井石油化学)

25）ドイッ特許 DT 1770725 (Hoechst)

26) 日特公昭43-13050 (Solvay)

27) NO 7302337, 7302338 (BASF)

NL 7307180 (Naphtachimie)

BE 807722 (Solvay)

BE 813624 (Standard Oi1)

28）日特公 昭49-16782（チッソ）

29) Chem \& Eng. News, May 5, (1975) p.17

30）日特公 昭49-15044（旭化成）

31）日特公 昭49-24593 (三井東圧)

32）日特公 昭49-24:135（三菱油化）

33）酒井忠基：工業材料， 22，(No.6), 53 59 (1974)

34）浜谷資郎：Plastics Age Encyclopedia 售歩編, 83 96 (1974)

35a) H. Sueyoshi, Y. Kitaoka : Hydrocarbon Processing, 51, (No. 10) 161-163 (1972)

35b）村田勝英, 收野忠彦: 三井造船技報 86号, 23 30 (1974)

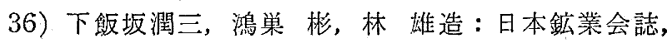
90, [12], 17-21 (1974)

37）竹内克行, 久保田辉男: 塩ビとポりマ-, 14, (No. 2), 18 22 (1974)

38）白特公 昭49-28034 (Air Product and Chem.)

39）日特公 昭49-20390 (Bayer)

40)程ビとポリマー，15，(No.4)26〜28（1975） 